\title{
Negative Balance of Calcium and Magnesium under Relatively Low Sodium Intake in Humans
}

\author{
Naoko KoDAma, Mamoru Nishimuta* and Kazumasa SuZuKI \\ Division of Human Nutrition, The National Institute of Health and Nutrition, Tokyo 162-8636, Japan
}

(Received January 11, 2003)

\begin{abstract}
Summary The balance of minerals (sodium [Na], potassium [K], calcium [Ca], and magnesium $[\mathrm{Mg}]$ ) was measured in six female students for $10 \mathrm{~d}$ while under a relatively low $\mathrm{Na}$ intake $(100 \mathrm{mmol} / \mathrm{d}$ or $2.2 \mathrm{~g} / \mathrm{d})$ with receiving adequate $\mathrm{Ca}(20 \mathrm{mmol} / \mathrm{d}$ or $800 \mathrm{mg} / \mathrm{d})$ and $\mathrm{Mg}(12 \mathrm{mmol} / \mathrm{d}$ or $280 \mathrm{mg} / \mathrm{d})$. Both the plasma renin activity (PRA) and aldosterone level were above the reference ranges throughout the experiment, which implied that the subjects were $\mathrm{Na}$ deficient. However, the urine $\mathrm{Na}$ excretion was about the same as that ingested, while there was no substantial reduction of sweat Na concentration observed during moderate physical exercise $(13.2 \pm 2.6 \mathrm{mmol} / \mathrm{L})$ (mean $\pm \mathrm{SD})$. On the other hand, the urine $\mathrm{Ca}$ and $\mathrm{Mg}$ levels were high, but the apparent absorption of $\mathrm{Ca}$ and $\mathrm{Mg}$ was moderate $(21 \pm 5 \%, 34 \pm 4 \%$, respectively), which resulted in a negative balance of these two elements. It seems that the stored $\mathrm{Na}$ in the bone is eluted so as to compensate for the low dietary $\mathrm{Na}$ intake, while any excess $\mathrm{Ca}$ and $\mathrm{Mg}$ also inevitably flows into the blood stream with $\mathrm{Na}$, which inhibited the intestinal absorption of both $\mathrm{Ca}$ and $\mathrm{Mg}$ and accelerates their excretion in urine.
\end{abstract}

Key Words balance, sodium, calcium, magnesium, human

In our previous study (1), unexpected results were demonstrated in the arm sweat contents of sodium $(\mathrm{Na})$, calcium $(\mathrm{Ca})$, and magnesium $(\mathrm{Mg})$ of young Japanese females during relatively heavy bicycle ergometer exercise $(1.5 \mathrm{kp}, 50 \mathrm{rpm}, 66 \mathrm{~min}$, twice a day) while taking a relatively low mineral diet with dietary $\mathrm{Na}$ of $100 \mathrm{mmol} / \mathrm{d}$ (or sodium chloride $6 \mathrm{~g} / \mathrm{d}$ ).

The sweat $\mathrm{Na}$ was relatively lower, but the sweat $\mathrm{Ca}$ and $\mathrm{Mg}$ were obviously higher during the experiment as compared to identical experiments in which the dietary $\mathrm{Na}$ was $170 \mathrm{mmol} / \mathrm{d}$ (or sodium chloride $10 \mathrm{~g} / \mathrm{d}$ ) (2).

Although no reasonable hypothesis has yet been made to explain these results, one assumption has been proposed (3). Regarding the aspect of nutrition, these three minerals are all stored in the bone (4). Therefore, when any of these minerals reaches an insufficient level in the body, it is eluted from the bone to compensate for any shortage. The mechanism of elution of these minerals from the bone was reported to occur through nonmineral selective osteolysis by the macrophages (5).

If this mechanism occurs under $\mathrm{Na}$ restriction, then excess $\mathrm{Ca}$ and $\mathrm{Mg}$ may also be eluted along with the $\mathrm{Na}$, and thus flow into the blood stream, and thereby inevitably cause a reduction of intestinal absorption as well as an increase in the urine excretion of these minerals.

\footnotetext{
* To whom correspondence should be addressed.

E-mail: nisimuta@nih.go.jp

Granted from Environmental Agency, Health Science Foundation, Uehara Memorial Foundation, The Salt Science Research Foundation (Japan) and Ministry of Health Labor and Welfare.
}

The aim of this study was to measure the balance of minerals ( $\mathrm{Na}, \mathrm{K}, \mathrm{Ca}$, and $\mathrm{Mg}$ ) as well as to evaluate the hormones affecting the $\mathrm{Na}$ metabolism in humans under a low $\mathrm{Na}$ intake.

\section{SUBJECTS AND METHODS}

This study was carried out according to the rules of the Helsinki Declaration, and was approved by the ethical committee of the National Institute of Health and Nutrition, Tokyo. A 17-d metabolic study, including two successive balance sessions of $5 \mathrm{~d}$, was designed as shown in Table 1. Six female students took part in this study after giving their written informed consent and also receiving a full explanation of the purpose and methods of this experiment (Table 2). After examination of the first blood specimen, all subjects were regarded to be in good health. The subjects reported to the metabolic ward at the National Institute of Health and Nutrition in the afternoon before supper on day 1 and ate as much as they desired; they then went to bed at the scheduled time of 10:00 p.m.

During the period, starting from 6:00 a.m. on day 2 and ending at 8:30 a.m. on day 17, urine specimens were collected, and the 24-h urine and/or partition urine (on days 2,7 and 12) excretion of minerals ( $\mathrm{Na}, \mathrm{K}$, $\mathrm{Ca}$, and $\mathrm{Mg}$ ) was measured. On the morning of days 4 , 9 , and 14 , the fasting morning blood was sampled, and the subjects also orally took a coloring marker for their feces (Carmine $0.5 \mathrm{~g}$ : Merk KGaA, Germany) just before breakfast.

Three subjects (a, c, e) pedaled a bicycle ergometer for 60 min once a day at the subject's selected intensity 
Table 1. Experimental design.

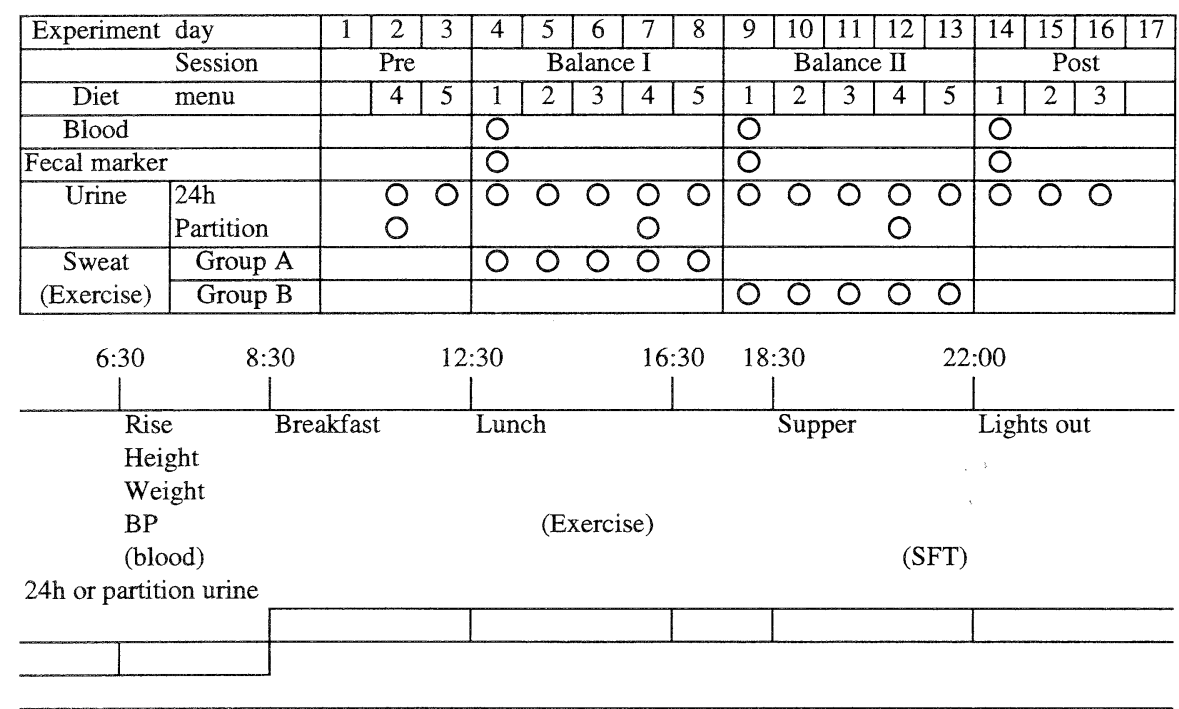

BP, blood pressure; SFT, skin fold thickness.

Table 2. Characteristics of subjects.

\begin{tabular}{|c|c|c|c|c|c|c|c|c|c|c|c|c|c|c|c|}
\hline & \multirow{2}{*}{ ID } & \multirow{2}{*}{ Gender } & \multirow{2}{*}{$\begin{array}{c}\text { Age } \\
(y)\end{array}$} & \multicolumn{2}{|c|}{ Height $(\mathrm{cm})$} & \multicolumn{2}{|c|}{ Weight (kg) } & \multicolumn{2}{|c|}{$\mathrm{SBP}(\mathrm{mmHg})$} & \multicolumn{2}{|c|}{$\mathrm{DBP}(\mathrm{mmHg})$} & \multicolumn{2}{|c|}{$\mathrm{SFT}(\mathrm{mm})^{1}$} & \multicolumn{2}{|c|}{$\mathrm{Hb}(\mathrm{g} / \mathrm{dL})$} \\
\hline & & & & First & Last & First & Last & First & Last & First & Last & First & Last & First & Last \\
\hline \multirow[t]{3}{*}{ Group A } & $\mathrm{a}$ & $\mathrm{f}$ & 22 & 160.0 & 160.4 & 54.34 & 53.21 & 118 & 102 & 68 & 58 & 34.5 & 32.5 & 12.5 & 12.5 \\
\hline & $c$ & $\mathrm{f}$ & 21 & 163.8 & 163.9 & 57.74 & 57.33 & 124 & 106 & 80 & 68 & 38.0 & 32.0 & 14.6 & 14.2 \\
\hline & $\mathrm{e}$ & $\mathrm{f}$ & 22 & 143.3 & 144.6 & 51.63 & 51.41 & 104 & 104 & 68 & 56 & 55.0 & 50.5 & 13.0 & 12.9 \\
\hline \multirow[t]{8}{*}{ Group B } & $\mathrm{b}$ & $\mathrm{f}$ & 21 & 158.1 & 158.1 & 57.74 & 57.56 & 96 & 90 & 58 & 60 & 27.0 & 26.5 & 13.3 & 13.0 \\
\hline & $\mathrm{d}$ & $\mathrm{f}$ & 18 & 156.8 & 155.7 & 52.98 & 53.59 & 140 & 110 & 64 & 60 & 44.0 & 40.5 & 13.1 & 12.4 \\
\hline & f & $\mathrm{f}$ & 19 & 154.0 & 155.4 & 51.21 & 50.68 & 100 & 100 & 60 & 58 & 32.5 & 27.5 & 13.7 & 13.3 \\
\hline & \multirow{2}{*}{\multicolumn{2}{|c|}{$\begin{array}{l}\text { Mean } \\
\text { SD }\end{array}$}} & 21 & 156.0 & 156.4 & 54.27 & 53.96 & 114 & 102 & 66 & 60 & 38.5 & 34.9 & 13.4 & 13.1 \\
\hline & & & 2 & 7.0 & 6.6 & 2.90 & 2.91 & 17 & 7 & 8 & 4 & 9.9 & 9.1 & 0.7 & 0.7 \\
\hline & \multicolumn{3}{|l|}{$p$} & \multicolumn{3}{|c|}{0.199} & 0.119 & \multicolumn{2}{|r|}{$0.030^{*}$} & \multicolumn{2}{|r|}{$0.023^{*}$} & \multicolumn{2}{|c|}{$0.004^{* *}$} & \multicolumn{2}{|r|}{$0.013^{*}$} \\
\hline & \multirow{2}{*}{ ID } & \multirow{2}{*}{ Gender } & \multirow{2}{*}{$\begin{array}{l}\text { Age } \\
(\mathrm{y})\end{array}$} & \multicolumn{2}{|c|}{$\begin{array}{c}\mathrm{TP} \\
(\mathrm{g} / \mathrm{dL})\end{array}$} & \multicolumn{2}{|c|}{$\begin{array}{l}\text { Glucose } \\
(\mathrm{mg} / \mathrm{dL})\end{array}$} & \multicolumn{2}{|c|}{$\begin{array}{l}\text { T. Chol } \\
\text { (mg/dL) }\end{array}$} & \multicolumn{2}{|c|}{$\begin{array}{l}\text { HDL-C } \\
(\mathrm{mg} / \mathrm{dL})\end{array}$} & \multicolumn{2}{|c|}{$\begin{array}{c}\mathrm{TG} \\
(\mathrm{mg} / \mathrm{dL})\end{array}$} & \multicolumn{2}{|c|}{$\begin{array}{c}\text { Urate } \\
\text { (mg/dL) }\end{array}$} \\
\hline & & & & First & Last & First & Last & First & Last & First & Last & First & Last & First & Last \\
\hline \multirow[t]{3}{*}{ Group A } & a & $\mathrm{f}$ & 22 & 7.0 & 7.0 & 91 & 83 & 187 & 189 & 64 & 64 & 49 & 58 & 5.1 & 4.6 \\
\hline & $\mathrm{c}$ & $\mathrm{f}$ & 21 & 6.8 & 6.9 & 92 & 87 & 180 & 180 & 59 & 57 & 56 & 43 & 6.2 & 6.0 \\
\hline & e & f & 22 & 6.5 & 6.8 & 93 & 87 & 168 & 161 & 49 & 49 & 68 & 55 & 5.7 & 5.7 \\
\hline \multirow[t]{6}{*}{ Group B } & $b$ & $\mathrm{f}$ & 21 & 7.3 & 7.3 & 86 & 88 & 186 & 173 & 53 & 55 & 75 & 47 & 4.7 & 5.3 \\
\hline & d & $\mathrm{f}$ & 18 & 7.3 & 7.1 & 92 & 77 & 194 & 191 & 66 & 64 & 59 & 40 & 3.9 & 4.3 \\
\hline & $\mathrm{f}$ & $\mathrm{f}$ & 19 & 6.9 & 7.1 & 89 & 85 & 183 & 172 & 62 & 65 & 43 & 34 & 4.1 & 4.2 \\
\hline & Mean & & 21 & 7.0 & 7.0 & 91 & 85 & 183 & 178 & 59 & 59 & 58 & 46 & 5.0 & 5.0 \\
\hline & SD & & 2 & 0.3 & 0.2 & 3 & 4 & 9 & 11 & 7 & 6 & 12 & 9 & 0.9 & 0.8 \\
\hline & $p$ & & & & 0.197 & & $0.023^{*}$ & & $0.041^{*}$ & & 0.425 & & $0.030^{*}$ & & 0.349 \\
\hline
\end{tabular}

The data obtained at first and last specimen are shown.

${ }^{1}$ SFT, skin fold thickness (sum of upper arm back and subscapla); S(D)BP, systolic (diastolic) blood pressure; Hb, hemoglobin concentration; TP, total protein; T. Chol, total cholesterol; HDL-C, HDL cholesterol; TG, triglyceride.

${ }^{*} p<0,05,{ }^{* *} p<0.01$ (paired $t$-test). 
Table 3. Dietary intake of energy and nutrients per day.

\begin{tabular}{|c|c|c|c|c|c|c|c|c|}
\hline Items & Calculated $^{1}$ & & & & & Measure & & \\
\hline Energy & $7,500 \mathrm{~kJ}(1,800 \mathrm{kcal})$ & & & & & & & \\
\hline Protein & $84 \mathrm{~g}$ & & & & & & & \\
\hline Carbohydrate & $260 \mathrm{~g}$ & & & Menu & & & & \\
\hline Lipid & $24 \%$ of energy & No. 1 & No. 2 & No. 3 & No. 4 & No. 5 & Mean \pm SD (mg) & Mean \pm SD $(\mathrm{mmol})$ \\
\hline $\begin{array}{l}\mathrm{Na} \\
\text { (as } \mathrm{NaCl} \text { ) }\end{array}$ & $5.8 \mathrm{~g}$ & 2,200 & 2,300 & 2,300 & 2,200 & 2,200 & $2,200 \pm 100$ & $96 \pm 5$ \\
\hline $\mathrm{K}$ & $3.3 \mathrm{~g}$ & 2,800 & 2,800 & 2,200 & 3,000 & 2,600 & $2,700 \pm 300$ & $69 \pm 8$ \\
\hline $\mathrm{Ca}$ & $830 \mathrm{mg}$ & 870 & 750 & 710 & 900 & 770 & $800 \pm 80$ & $20 \pm 2$ \\
\hline $\mathrm{Mg}$ & $280 \mathrm{mg}^{2}$ & 290 & 270 & 260 & 280 & 320 & $280 \pm 20$ & $12 \pm 1$ \\
\hline $\mathrm{P}$ & $1,500 \mathrm{mg}$ & 1,490 & 1,590 & 1,570 & 1,720 & 1,780 & $1,630 \pm 120$ & $53 \pm 4$ \\
\hline $\mathrm{Fe}$ & $17 \mathrm{mg}$ & 17 & 37 & 17 & 32 & 33 & $27 \pm 9$ & $0.49 \pm 0.17$ \\
\hline $\mathrm{Zn}$ & & 28 & 28 & 27 & 26 & 30 & $28 \pm 2$ & $0.43 \pm 0.02$ \\
\hline $\mathrm{Cu}$ & & 3.7 & 4.2 & 3.9 & 3.6 & 7.6 & $4.6 \pm 1.7$ & $0.072 \pm 0.027$ \\
\hline Mn & & 3.5 & 3.7 & 3.7 & 3.8 & 4.7 & $3.9 \pm 0.5$ & $0.070 \pm 0.008$ \\
\hline
\end{tabular}

${ }^{1}$ After adding our data in minerals for foods not appeared in the tables (semidried oysters and smoked pork liver) (7).

${ }^{2}$ Based on salt-free ash (SFA) (11).

(1.25-1.5 kp, 50-60 rpm) during the Balance I session. The other three subjects $(b, d, f)$ did the same during the Balance II session. Arm sweat during exercise was collected after cleaning the skin surface with pure water and ion-free treated gauze with ethylene-diamine-tetraacetic acid, diammonium salt (EDTA: Wako Pure Chemical Ind., Ltd., Japan), with the whole arm covered with a long polyethylene bag wrapped with tape. The collected sweat was filtered with a $0.10 \mu \mathrm{m}$ pore size Teflon filter (Fluoro pore, Sumitomo Electric Ind. Ltd., Japan) and ethanol (for trace analysis, Wako Pure Chemical Ind. Ltd.) to remove any solids.

The diets supplied during the experiment consisted of a 5-d rotating menu and met all normal dietary allowances in Japan (6) as calculated by the food tables (Table 3) (7). To obtain the same quantities of constituents, all foodstuffs were carefully weighed before preparing the dishes $(8)$.

Duplicated and homogenized diets were triplicate sampled, and wet- ashed by hot plates using nitric acid (UGR for trace analysis, Kanto Chemical Co., Ltd., Japan) and hydrogen peroxide (for an atomic absorption analysis, Wako Pure Chemical Ind., Ltd.).

Fecal specimens were collected throughout the experiment and were separated into those originating in the diet during the first and second balance periods according to the ingested coloring marker appearing in the feces. All homogenized fecal samples were treated the same as the diet samples.

In order to obtain an adequate concentration for analysis, all samples (ashed diets, ashed feces, urine and filtered sweats) were diluted with the $0.5 \mathrm{~N}$ nitric acid solution. For the determination of $\mathrm{Ca}$, strontium chloride (for atomic absorption analysis, Wako Pure Chemical Ind., Ltd.) was added to the sample at a final concentration of 2,500 ppm.

The minerals ( $\mathrm{Na}, \mathrm{K}, \mathrm{Ca}$, and $\mathrm{Mg}$ and dietary iron ([Fe]), zinc $[\mathrm{Zn}]$, copper $[\mathrm{Cu}]$, and manganese $[\mathrm{Mn}])$ were analyzed by an atomic absorption spectrophotom- eter (AAS) (Varian AA-5, Australia) using an air-acetylene (for atomic absorption analysis, Toho Acetylene Co., Ltd., Japan) flame.

To determine the Ca levels by this technique, the $\mathrm{pH}$ of the standard solution is known to affect the absorption factor (9). Therefore, the height of the burner was adjusted to obtain the same absorption factor in standard solutions having different $\mathrm{pHs}$ before measuring the Ca. The dietary phosphorus (P) and urine creatinine were measured by the Fiske-SubbaRow and FolinWu methods, respectively (10).

Blood specimens were measured in a commercial laboratory (Biomedical Laboratories, Tokyo, Japan).

For the statistical analysis, the paired $t$-test after ANOVA was used.

\section{RESULTS}

Diet

The dietary mineral contents during the 10-d balance sessions are shown in Table 3. The dietary Na, Ca, and $\mathrm{Mg}$ were almost the same as that estimated by the Tables $(7,11)$. However, those of $\mathrm{K}$ and $\mathrm{P}$ were $80 \%$ and $110 \%$ of the estimated values, respectively.

24-h urine

The 24-h urine mineral excretion is shown in Fig. 1. The values for $\mathrm{Na}$, on days menu 4 was provided, were significantly higher than those for menu $5(p<0.05$, paired $t$-test). Those during the balance sessions were a little below the $\mathrm{Na}$ intake.

The values for $\mathrm{K}$ throughout the experiment were about $80 \%$ of the intake, as is often the case in such experiments (unpublished observation). The values for $\mathrm{K}$ on days menu 4 was provided were also significantly higher than those for menu 5 ( $p<0.05$, paired $t$-test).

However, the values for $\mathrm{Ca}$ throughout the experiment were higher than those in our previous experiments, and also higher than those reported in other literature (12) where less than $200 \mathrm{mg} / \mathrm{d}$ of 24 -h urine Ca was reported to be normal. The values for $\mathrm{Ca}$ on days 

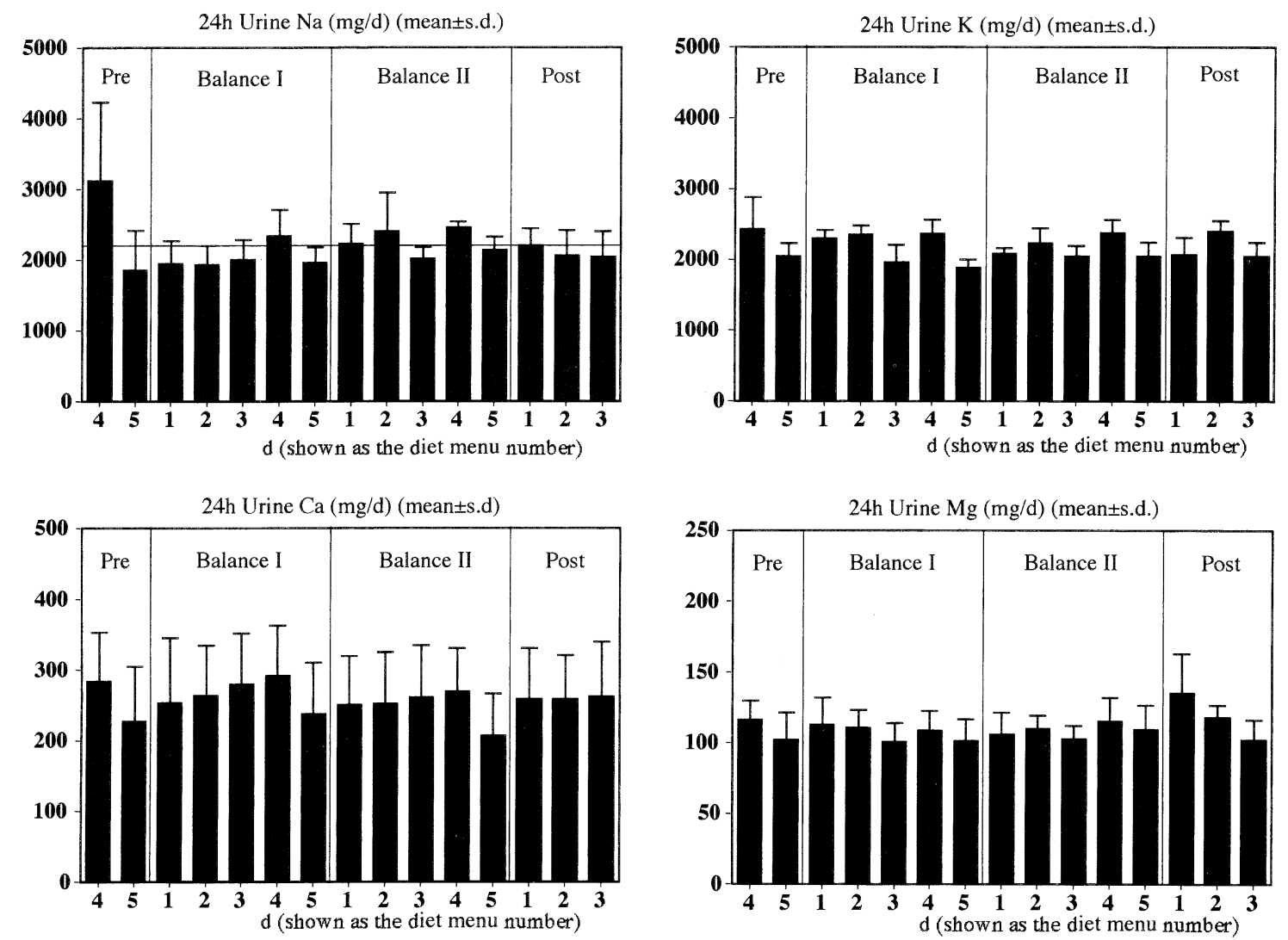

Fig. 1. The 24-h urine sodium (Na), calcium (Ca), potassium (K), and magnesium $(\mathrm{Mg})$ excretion from female students $(n=6)$ under low Na intake throughout the experiment. Mean daily dietary Na intake was $2.2 \mathrm{~g}(100 \mathrm{mmol} / \mathrm{d})$ as shown by the horizontal bar in the figure of $\mathrm{Na}$ excretion. The Na intake for each menu was 2.2, 2.3, 2.3, 2.2, and 2.0 g/d, respectively, in numerical order. However, the $24-\mathrm{h}$ urine $\mathrm{Na}$ on the days menu 4 was fed was significantly higher than that of diet menu 5 in the first three sessions ( $p<0.05$, paired $t$-test). On the other hand, the $\mathrm{K}$ intake in each menu was 2.8 , $2.8,2.2,3.1$, and $2.6 \mathrm{~g} / \mathrm{d}$, respectively, in numerical order. Note that the urine $\mathrm{Ca}$ and $\mathrm{Mg}$ excretions were high in this experiment.

menu 4 was provided were also significantly higher than those for menu 5 ( $p<0.05$, paired $t$-test).

The values for $\mathrm{Mg}$ throughout the experiment were higher than those measured in our previous experiments except for the Mg supplement study (13), but they were within the reference ranges according to previous reports $(8-15 \mathrm{mEq} / \mathrm{d}[4-7.5 \mathrm{mmol} / \mathrm{d}]$ or $3.7-$ $12.9 \mathrm{mEq} / \mathrm{d}$ [1.9-6.5 mmol/d]) (14).

Serum minerals and serum or plasma hormones

The minerals in the fasting morning serum are shown in Table 4. The serum Na (S-Na) was significantly lower in the final specimen than that in the other specimens. The serum $\mathrm{Mg}$ (S-Mg) was significantly higher in the first specimen than in other specimens. However, no significant changes were observed in either $\mathrm{Ca}$ or $\mathrm{K}$.

The plasma renin activity (PRA), angiotensin I (Angio I), and aldosterone (Ald) concentration showed higher values than those in the reference range indicated in the laboratory data throughout the experiment (Table 5).

A slight but significant decrease within the reference ranges in triiodothyronine (T3), thyroxin (T4), and insulin (IRI) were also observed. Among them, changes in T3 and T4 were often observed without low Na intake in our laboratory. However, significant changes in IRI during the experiment were observed only in this experiment.

Partition urine minerals on days 2, 7, and 12 on days menu 4 was provided

Partition urine (PU) minerals ( $\mathrm{Na}, \mathrm{K}, \mathrm{Ca}$, and $\mathrm{Mg}$ ) on days 2,7 , and 12 , where menu 4 was supplied, are shown in Fig. 2. The mean level of PU-Na on day 2 between 8:30 and 18:30 was higher than that on other

Table 4. The contents of serum minerals on the fasted morning (mean $\pm \mathrm{SD})$.

\begin{tabular}{lcll}
\hline \multicolumn{1}{c}{ Items } & Day 4 & \multicolumn{1}{c}{ Day 9} & Day 14 \\
\hline $\mathrm{Na}(\mathrm{mmol} / \mathrm{L})$ & $140 \pm 2^{\text {aaa }}$ & $140 \pm 1^{\text {bbb }}$ & $137 \pm 1^{\text {aaa }, \mathrm{bbb}}$ \\
$\mathrm{Cl}(\mathrm{mmol} / \mathrm{L})$ & $105 \pm 2$ & $103 \pm 2$ & $104 \pm 1$ \\
$\mathrm{~K}(\mathrm{mmol} / \mathrm{L})$ & $4.1 \pm 0.2$ & $4.1 \pm 0.1$ & $4.1 \pm 0.1$ \\
$\mathrm{Ca}(\mathrm{mmol} / \mathrm{L})$ & $4.4 \pm 0.1$ & $4.4 \pm 0.2$ & $4.5 \pm 0.1$ \\
$\mathrm{Mg}(\mathrm{mg} / \mathrm{dL})$ & $1.9 \pm 0.1^{\mathrm{a}, \mathrm{b}}$ & $1.8 \pm 0.1^{\mathrm{a}}$ & $1.7 \pm 0.1^{\mathrm{b}}$ \\
$\mathrm{iP}(\mathrm{mg} / \mathrm{dL})$ & $3.7 \pm 0.2$ & $3.6 \pm 0.3$ & $3.8 \pm 0.2$ \\
\hline
\end{tabular}

${ }^{\text {a,b }} p<0.05$, aaa,bbb $p<0.001$ between the same letters (paired $t$-test).

iP, inorganic phosphate. 
Table 5. The concentration of serum or plasma hormones on the fasted morning.

\begin{tabular}{llcrc}
\hline \multicolumn{1}{c}{ Items } & Reference range & Day 4 & Day 9 & Day 14 \\
\hline PRA $(\mathrm{ng} / \mathrm{mL} / \mathrm{h})$ & $0.1-2.0$ & $4.1 \pm 1.8^{\mathrm{a}}$ & $3.4 \pm 1.9$ & $3.0 \pm 1.7^{\mathrm{a}}$ \\
Angio I $(\mathrm{pg} / \mathrm{mL})$ & less than 180 & $194 \pm 78$ & $158 \pm 49$ & $121 \pm 75$ \\
Angio II $(\mathrm{pg} / \mathrm{mL})$ & less than 50 & $17 \pm 9$ & $22 \pm 9^{\mathrm{a}}$ & $13 \pm 4^{\mathrm{a}}$ \\
Ald $(\mathrm{ng} / \mathrm{dL})$ & less than 18.0 & $27.1 \pm 9.3$ & $19.8 \pm 6.1$ & $22.0 \pm 3.7$ \\
Insulin $(\mu \mathrm{U} / \mathrm{mL})$ & $3-18$ & $9 \pm 3^{\mathrm{a}}$ & $8 \pm 2^{\mathrm{b}}$ & $7 \pm 1^{\mathrm{a}, \mathrm{b}}$ \\
T3 $(\mathrm{ng} / \mathrm{dL})$ & $80-180$ & $132 \pm 26^{\mathrm{a}}$ & $8.3 \pm 18^{\mathrm{b}}$ & $106 \pm 12^{\mathrm{a}, \mathrm{b}}$ \\
T4 $(\mu \mathrm{g} / \mathrm{dL})$ & $5.0-14.0$ & $8.3 \pm 1.3^{\mathrm{a}}$ & $8.1 \pm 1.4^{\mathrm{b}}$ & $7.5 \pm 1.0^{\mathrm{a}, \mathrm{b}}$ \\
\hline
\end{tabular}

${ }^{\mathrm{a}, \mathrm{b}} p<0.05$ between the same letters (paired $t$-test) (mean \pm SD).

PRA, plasma renin activity; Angio, angiotensin; Ald, aldosteron; T3, triiodothyronine; T4, thyroxin.
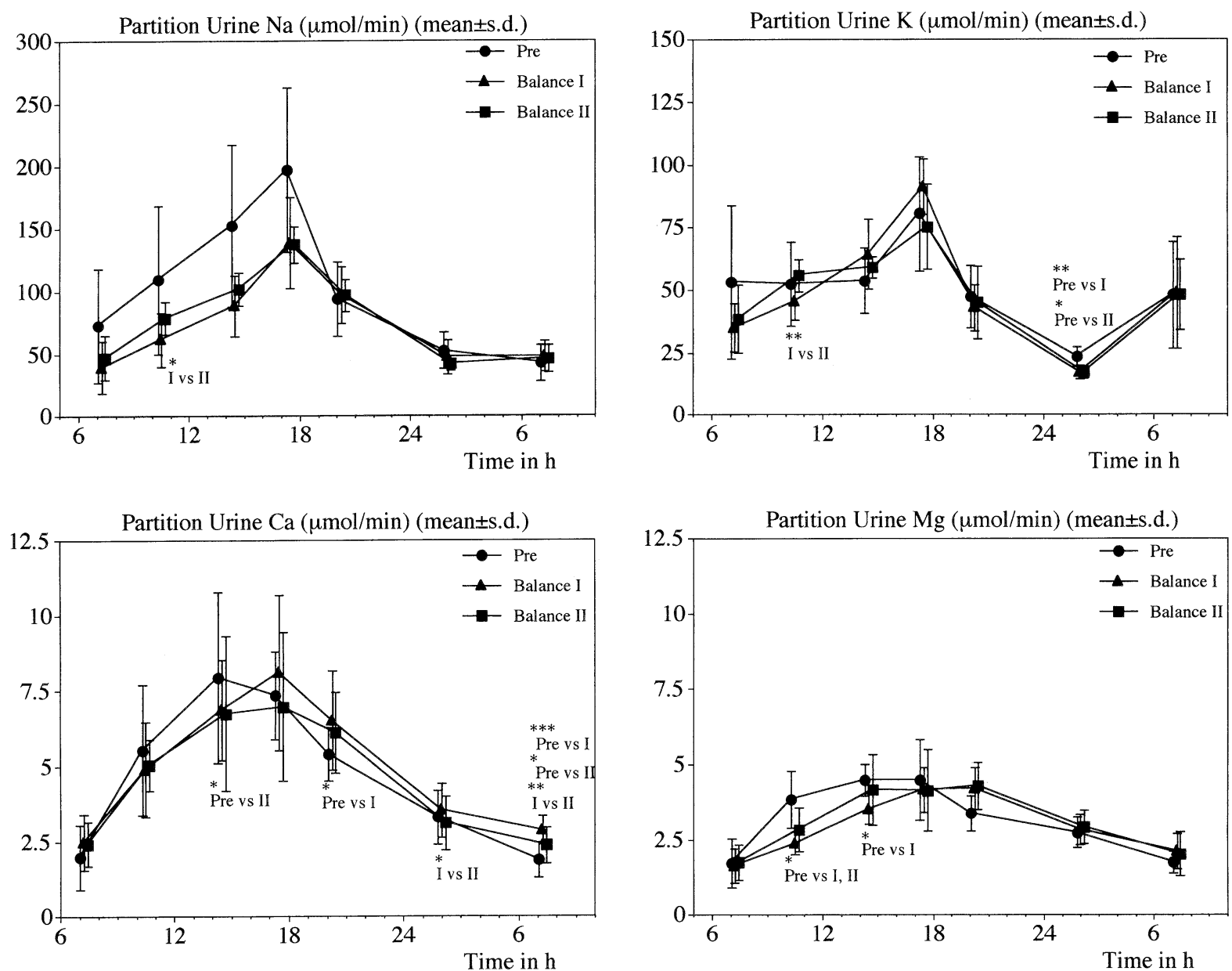

Fig. 2. Partition urine minerals (sodium [Na], calcium [Ca], potassium [K], and magnesium $[\mathrm{Mg}]$ ) on the three days when menu 4 was consumed (mean \pm sd). Urine was sampled at 06:00 (night), 08:30 (before breakfast; early morning), 12:30 (before lunch; morning), 16:30 (afternoon), 18:30 (before supper), and at 22:00 (before sleep). Values are plotted at the center of each interval $\left({ }^{*} p<0.05,{ }^{* *} p<0.01,{ }^{* * *} p<0.001\right.$ paired $t$-test).

days but the difference was not significant. The levels of PU-Na between 22:00 and 8:30 the next morning were almost the same for all $3 \mathrm{~d}$. Some differences were significant in PU-K, PU-Ca, and PU-Mg.

Sweat minerals.

The concentration of arm sweat minerals ( $\mathrm{Na}, \mathrm{K}, \mathrm{Ca}$, and $\mathrm{Mg}$ ), and the estimated sweat loss (mineral concentration $\times$ body weight loss) during exercise are shown in Table 6 . The sweat $\mathrm{Na}$ concentration (sw-Na) was not reduced, and sw-Ca and Mg were not as high as was previously reported (1).

Balance of minerals

The results of the balance of the minerals ( Na, K, Ca, and $\mathrm{Mg}$ ) in this study were calculated as those during the whole balance period $(10 \mathrm{~d})$ and the findings are shown in Table 7 . The Na balance was slightly negative, while the $\mathrm{Ca}$ and $\mathrm{Mg}$ balances were obviously negative and the $\mathrm{K}$ balance was slightly positive in this experiment. 
Table 6. Arm sweat content and estimated dermal loss of minerals.

\begin{tabular}{|c|c|c|c|c|}
\hline & \multicolumn{2}{|r|}{$\mathrm{Na}$} & \multicolumn{2}{|r|}{$\mathrm{K}$} \\
\hline & Concentration $(\mathrm{mmol} / \mathrm{L})$ & Dermal output (mmol/trial) & Concentration $(\mathrm{mmol} / \mathrm{L})$ & Dermal output (mmol/trial) \\
\hline \multirow[t]{3}{*}{$\begin{array}{l}\text { Mean } \pm S D \\
\text { (range) }\end{array}$} & $\begin{array}{l}13.2 \pm 2.6 \\
(9.4-20.7)\end{array}$ & $\begin{array}{c}8.0 \pm 2.5 \\
(4.3-18.8)\end{array}$ & $\begin{array}{c}4.5 \pm 1.8 \\
(5.4-11.9)\end{array}$ & $\begin{array}{c}4.5 \pm 0.4 \\
(3.2-6.7)\end{array}$ \\
\hline & \multicolumn{2}{|r|}{$\mathrm{Ca}$} & \multicolumn{2}{|r|}{$\mathrm{Mg}$} \\
\hline & Concentration $(\mathrm{mmol} / \mathrm{L})$ & Dermal output (mmol/trial) & Concentration $(\mathrm{mmol} / \mathrm{L})$ & Dermal output (mmol/trial) \\
\hline $\begin{array}{l}\text { Mean } \pm S D \\
\text { (range) }\end{array}$ & $\begin{array}{c}0.39 \pm 0.11 \\
(0.26-1.01)\end{array}$ & $\begin{array}{c}0.23 \pm 0.04 \\
(0.14-0.31)\end{array}$ & $\begin{array}{c}0.11 \pm 0.13 \\
(0.03-0.41)\end{array}$ & $\begin{array}{c}0.07 \pm 0.10 \\
(0.02-0.31)\end{array}$ \\
\hline
\end{tabular}

Arm sweat was collected during 60 min of moderate exercise under low Na intake of $2.2 \mathrm{~g} / \mathrm{d}(n=30$; mean of six subjects in five trials).

Dermal output of minerals ( $\mathrm{Na}, \mathrm{K}, \mathrm{Ca}$ and $\mathrm{Mg}$ ) is calculated by multiplying the concentration by body weight loss.

\section{DISCUSSION}

\section{Estimation of Na deficiency in this study}

The dietary Na content in this study of $100 \mathrm{mmol} / \mathrm{d}$ was half as much as that observed in a normal dietary supply of $200 \mathrm{mmol} / \mathrm{d}$ or more for Japanese. However, it is difficult to determine whether or not $\mathrm{Na}$ was deficient in this study, because Na deficiency itself has yet to be clearly defined.

It is generally believed that urine $\mathrm{Na}$ excretion is restricted by decreasing renal plasma flow and/or increasing tubular reabsorption with the homeostatic action of some mechanisms including the renin-angiotensin-aldosterone system to maintain the plasma $\mathrm{Na}$ concentration as well as the plasma volume if the dietary $\mathrm{Na}$ is limited. In addition, there are still no known objective symptoms illustrating $\mathrm{Na}$ deficiency in humans. However, desirable $\mathrm{Na}$ is known to be an objective symptom in some animals that have Na deficiency, and this phenomenon is called a "salt appetite."

Consequently, in Japan and the United States (15, 16), the Na requirement has been estimated by the minimum Na loss; that is, the sum of inevitable Na loss from the feces, urine, and skin when receiving no dietary Na supply. This Na requirement was evaluated without considering the existence of a $\mathrm{Na}$ pool in the body.

In our previous study (1), the lower $\mathrm{Na}$ and higher $\mathrm{Ca}$ and $\mathrm{Mg}$ contents in arm sweat during relatively heavy exercise under a relatively low dietary $\mathrm{Na}$ intake of $100 \mathrm{mmol} / \mathrm{d}$ suggested both the presence of $\mathrm{Na}$ deficiency in that study and the presence of a possible mechanism which compensates for the Na deficiency. The proposed mechanism is considered to act via the elution of $\mathrm{Na}$ from the bone, where $50 \%$ of the bodily $\mathrm{Na}$ is known to be stored. Although it is only one of the minor elements in the bone, Na elution from the bone inevitably exceed that of such major minerals as $\mathrm{Ca}$. In our previous study, the low $\mathrm{Na}$ and high $\mathrm{Ca}$ and $\mathrm{Mg}$ concentrations in arm sweat during relatively heavy exercise were considered to be the result of increased bone resorption.

This study confirmed existence of the mechanism and illustrated in a balanced technique, that is, the high urine excretions of $\mathrm{Ca}$ and $\mathrm{Mg}$, and, the negative balances of $\mathrm{Ca}$ and $\mathrm{Mg}$, which did not compensate for any increased intestinal absorption under a sufficient dietary intake of $\mathrm{Ca}$ and $\mathrm{Mg}$. These results also suggest an increase in bone resorption, although a direct marker for bone metabolism was not measured in this experiment. Further experimentation is needed to clarify this. In this mechanism, not $\mathrm{Ca}$, but Na thus appears to play the leading role in osteolysis.

In this study, it is further possible to indirectly illustrate the existence of $\mathrm{Na}$ deficiency based on the data that the serum $\mathrm{Na}$ concentration decreased in the final specimen, while the activity in the renin-angiotensinaldosterone system, which enhanced the increased renal reabsorption of $\mathrm{Na}$, was higher than the reference ranges throughout the study. Therefore, the Na intake of $100 \mathrm{mmol} / \mathrm{d}$ or $2.2 \mathrm{~g} / \mathrm{d}$ for the subjects, especially in this study, was considered to be deficient, even though the sweat $\mathrm{Na}$ level was not low.

The Ca and $\mathrm{Mg}$ status in this study

In all subjects, Ca was negatively balanced, although this dietary mineral was not restricted. The dietary allowances of Ca have been assessed to be $600 \mathrm{mg} / \mathrm{d}$ in Japan (16), and 1,200 mg/d in the United States (15) for the same age and sex as the subjects of this experiment.

The dietary $\mathrm{Ca}$ in this experiment was $800 \mathrm{mg} / \mathrm{d}$, or in a range between the allowances for the Japanese and Americans. It is possible that the dietary Ca was deficient. However, in such a case, the urinary Ca would thus decrease, while the intestinal absorption would increase to compensate for the low dietary Ca level. In this experiment, the urinary Ca was high while the intestinal absorption was not high, and thus the authors concluded that the dietary Ca level was adequate in this experiment, even though the balance of $\mathrm{Ca}$ 
Table 7. Balance of sodium $(\mathrm{Na})$, potassium $(\mathrm{K})$, calcium (Ca), and magnesium $(\mathrm{Mg})$ under low $\mathrm{Na}$ intake in six female students for $10 \mathrm{~d}$.

Sodium (Na)

\begin{tabular}{lcccccr}
\hline Sub. & $\begin{array}{c}\text { Intake } \\
(\mathrm{g} / \mathrm{d})\end{array}$ & $\begin{array}{c}\text { Feces } \\
(\mathrm{g} / \mathrm{d})\end{array}$ & $\begin{array}{c}\text { Apparent } \\
\text { absorption }(\%)\end{array}$ & $\begin{array}{c}\text { Urine } \\
(\mathrm{g} / \mathrm{d})\end{array}$ & $\begin{array}{c}\text { Sweat* } \\
(\mathrm{g} / \mathrm{d})\end{array}$ & $\begin{array}{c}\text { Balance } \\
(\mathrm{g} / \mathrm{d})\end{array}$ \\
\hline $\mathrm{a}$ & 2.21 & 0.02 & 99 & 2.17 & 0.10 & -0.08 \\
$\mathrm{c}$ & 2.21 & 0.02 & 99 & 2.12 & 0.07 & 0.00 \\
$\mathrm{e}$ & 2.21 & 0.01 & 99 & 2.17 & 0.10 & -0.07 \\
$\mathrm{~b}$ & 2.21 & 0.01 & 99 & 2.19 & 0.02 & -0.01 \\
$\mathrm{~d}$ & 2.21 & 0.03 & 99 & 2.04 & 0.08 & 0.06 \\
$\mathrm{f}$ & 2.21 & 0.02 & 99 & 2.14 & 0.15 & -0.09 \\
\hline Mean & & 0.02 & 99 & 2.14 & 0.09 & -0.03 \\
SD & & 0.01 & 0 & 0.05 & 0.04 & 0.06 \\
\hline
\end{tabular}

Potassium (K)

\begin{tabular}{lcccccc}
\hline Sub. & $\begin{array}{c}\text { Intake } \\
(\mathrm{g} / \mathrm{d})\end{array}$ & $\begin{array}{c}\text { Feces } \\
(\mathrm{g} / \mathrm{d})\end{array}$ & $\begin{array}{c}\text { Apparent } \\
\text { absorption }(\%)\end{array}$ & $\begin{array}{c}\text { Urine } \\
(\mathrm{g} / \mathrm{d})\end{array}$ & $\begin{array}{c}\text { Sweat* } \\
(\mathrm{g} / \mathrm{d})\end{array}$ & $\begin{array}{c}\text { Balance } \\
(\mathrm{g} / \mathrm{d})\end{array}$ \\
\hline $\mathrm{a}$ & 2.71 & 0.37 & 86 & 2.17 & 0.09 & 0.07 \\
$\mathrm{c}$ & 2.71 & 0.29 & 89 & 2.30 & 0.09 & 0.04 \\
$\mathrm{e}$ & 2.71 & 0.34 & 87 & 2.14 & 0.07 & 0.16 \\
$\mathrm{~b}$ & 2.71 & 0.43 & 84 & 2.18 & 0.09 & 0.01 \\
$\mathrm{~d}$ & 2.71 & 0.33 & 88 & 1.97 & 0.09 & 0.33 \\
$\mathrm{f}$ & 2.71 & 0.30 & 89 & 2.18 & 0.09 & 0.14 \\
\hline Mean & & 0.34 & 87 & 2.16 & 0.09 & 0.12 \\
SD & & 0.05 & 2 & 0.11 & 0.01 & 0.12 \\
\hline
\end{tabular}

Calcium (Ca)

Sub. Intake Feces Apparent Urine Sweat* Balance (mg/d) (mg/d) absorption (\%) (mg/d) (mg/d) (mg/d)

\begin{tabular}{lrrrrrr}
\hline $\mathrm{a}$ & 802 & 593 & 26 & 337 & 5 & -132 \\
$\mathrm{c}$ & 802 & 593 & 26 & 312 & 4 & -106 \\
$\mathrm{e}$ & 802 & 643 & 20 & 285 & 5 & -130 \\
$\mathrm{~b}$ & 802 & 623 & 22 & 261 & 6 & -88 \\
$\mathrm{~d}$ & 802 & 694 & 13 & 171 & 5 & -68 \\
$\mathrm{f}$ & 802 & 643 & 20 & 175 & 5 & -21 \\
\hline Mean & & 631 & 21 & 275 & 5 & -91 \\
SD & 38 & 5 & 70 & 1 & 42 \\
\hline
\end{tabular}

Magnesium $(\mathrm{Mg})$

Sub Intake Feces Apparent Urine Sweat* Balance Sub. $(\mathrm{mg} / \mathrm{d})(\mathrm{mg} / \mathrm{d})$ absorption $(\%)(\mathrm{mg} / \mathrm{d})(\mathrm{mg} / \mathrm{d})(\mathrm{mg} / \mathrm{d})$

\begin{tabular}{lrrrrrr}
\hline a & 283 & 181 & 36 & 114 & 3 & -15 \\
c & 283 & 174 & 39 & 120 & 0 & -11 \\
e & 283 & 196 & 31 & 107 & 0 & -20 \\
b & 283 & 204 & 28 & 86 & 1 & -8 \\
d & 283 & 189 & 33 & 107 & 0 & -13 \\
$\mathrm{f}$ & 283 & 174 & 39 & 116 & 0 & -7 \\
\hline \multirow{2}{*}{ Mean } & & 186 & 34 & 108 & 1 & -12 \\
SD & & 12 & 4 & 12 & 1 & 5 \\
\hline
\end{tabular}

* Sweat loss of minerals were mean of $10 \mathrm{~d}$ with and without exercise. was negative.

The dietary minimum $\mathrm{Mg}$ requirement was considered to be $160 \mathrm{mg} / \mathrm{d}$ for the Japanese in our laboratory $(13,17)$. The dietary allowance of $\mathrm{Mg}$ is $280 \mathrm{mg} / \mathrm{d}$ in the United States (15) and $250 \mathrm{mg} / \mathrm{d}$ in Japan for the subjects (18).

Based on the above data, the dietary Mg was thus not considered to be deficient. However, it is still possible that there was a deficiency of $\mathrm{Mg}$. In such a case, the urinary $\mathrm{Mg}$ would decrease and intestinal absorption would increase to compensate for the low dietary $\mathrm{Mg}$ level.

The urinary $\mathrm{Mg}$ was high while the intestinal absorption was moderate, and thus the dietary $\mathrm{Mg}$ was not found to be deficient in this experiment, even though both the serum $\mathrm{Mg}$ decreased during the experiment, and the balance of $\mathrm{Mg}$ was also negative.

Dietary $\mathrm{Na}$ intake and urine $\mathrm{Ca}$ and $\mathrm{Na}$

On the other hand, it has been reported that an excess salt intake increases urine Ca excretion, and that the urine $\mathrm{Na}$ and $\mathrm{Ca}$ levels also showed a positive correlation (19), which thus suggested that sodium plays a completely different role in the $\mathrm{Ca}$ metabolism in this study.

In another previous balance study of ours, where salt was supplied on two levels in a crossover manner, the urine Ca excretion level during a session of higher salt intake was higher than that during lower salt intake (unpublished observation). As a result, the authors do not deny the presence of a possible mechanism in which an excess sodium intake causes an increase in urine Ca excretion by increasing the renal plasma flow.

In this experiment, the urine creatinine (the data is not shown in this paper) and the mineral ( $\mathrm{Na}, \mathrm{K}, \mathrm{Ca}$, and $\mathrm{Mg}$ ) excretions on the days that menu 4 was provided were significantly higher than those when menu 5 was fed. Therefore, the results of this experiment support, in part, the positive correlation between urine $\mathrm{Na}$ and $\mathrm{Ca}$ levels. This correlation between $\mathrm{Na}$ and $\mathrm{Ca}$ may be related to the dietary $\mathrm{K}$ intake following the increased urine $\mathrm{K}$ excretion in this experiment, as shown in Fig. 1. The decreased serum insulin during the experiment thus supported the hypothesis that the dietary $\mathrm{K}$ level was sufficient throughout the experiment. However, the correlation between the urine $\mathrm{Na}$ and $\mathrm{Ca}$ levels does not directly support the hypothesis that a high sodium intake leads to a negative balance of $\mathrm{Ca}$, which thereafter leads to the development of osteoporosis (19) because the intestinal absorption of $\mathrm{Ca}$ is also regulated.

Uresis of $\mathrm{Ca}$ and $\mathrm{Mg}$

Independent of the $\mathrm{Na}$ intake, various risk factors for chronic degenerative diseases such as physical and mental stress $(9,20)$, overeating $(20,21)$, and anaerobic exercise (2) also increase urine $\mathrm{Mg}$ and Ca levels. Under these circumstances, urine $\mathrm{Ca}$ and $\mathrm{Mg}$ are generally excreted in an isomolar ratio (same molar volume). To keep the plasma $\mathrm{Ca}$ constant, the $\mathrm{Ca}$ in the bone is eluted since the bone is the sole physiological Ca pool in the body. However, it is difficult to determine exactly 
which organ contributes to maintaining the plasma $\mathrm{Mg}$ at a constant level. If the plasma $\mathrm{Mg}$ was maintained not by soft tissue, but by the bone, extensive bone $\mathrm{Ca}$ would thus be eluted with the $\mathrm{Mg}$ from the bone because of the high $\mathrm{Ca} / \mathrm{Mg}$ molar ratio in the bone (at least more than five) (22). As a result, regarding the uresis of $\mathrm{Ca}$ and $\mathrm{Mg}$, at least some $\mathrm{Mg}$ must be delivered from the soft tissue in order to help protect the supply of the bone minerals, especially $\mathrm{Ca}(20)$.

In this experiment, the urine Ca level was much higher than that observed in other experiments $(9,13)$. It was also higher than that of $\mathrm{Mg}$ regarding the molar ratio. Even though the reason why the urine $\mathrm{Ca}$ was higher than that of $\mathrm{Mg}$ in this experiment could not be clarified, $\mathrm{Mg}$ in soft tissue does not appear to strongly contribute to the urine $\mathrm{Mg}$ level, in which $\mathrm{Na}$ is not physiologically stored.

Theory of osteoporosis without low dietary Ca intake

The results of this experiment as well as those of our previous studies $(1-3,9,20,21)$ strongly suggest that some mechanisms to remove bone minerals without low dietary Ca intake must exist, although no detailed mechanism has yet been identified. Those mechanisms may be activated when any of the minerals stored in the bone ( $\mathrm{Na}, \mathrm{Ca}, \mathrm{Mg}, \mathrm{P}$, and zinc [Zn]) become deficient in the body.

Due to such mechanisms, osteoporosis will inevitably progress even if the dietary Ca level is sufficient.

Ca metabolism in this experiment

It is possible that the high urine Ca excretion and negative Ca balance seen in this experiment could also be the result of some interaction between the Ca regulating hormones and the vitamins. However, these factors were not measured in this study.

Some circumstances, such as a high protein intake (23) or exposure to low gravity during space travel (2426), are already known to cause a negative $\mathrm{Ca}$ balance in spite of a sufficient dietary Ca intake.

The mechanism to illustrate such a negative Ca balance with sufficient $\mathrm{Ca}$ intake is usually not directly involved in the metabolism of minerals. However, our findings suggest that a negative Ca balance appears to be the result of a deficiency of other minerals stored in the bone $(1,2,9,20,21)$.

Although the negative $\mathrm{Ca}$ and $\mathrm{Mg}$ balances observed in this study have yet to be proven to be the result of $\mathrm{Na}$ deficiency, it should be kept in mind, when evaluating the sodium requirement that bone sodium is eluted when $\mathrm{Na}$ is deficient both in the body and when an excessive degree of bone resorption is induced.

\section{CONCLUSION}

The balances of minerals ( $\mathrm{Na}, \mathrm{K}, \mathrm{Ca}$, and $\mathrm{Mg}$ ) were measured under a relatively low $\mathrm{Na}$ intake $(100 \mathrm{mmol} /$ $\mathrm{d}$ or $2.2 \mathrm{~g} / \mathrm{d})$ with an adequate intake of $\mathrm{Ca}(20 \mathrm{mmol} / \mathrm{d}$ or $800 \mathrm{mg} / \mathrm{d})$ and $\mathrm{Mg}(12 \mathrm{mmol} / \mathrm{d}$ or $280 \mathrm{mg} / \mathrm{d})$ in six female students for $10 \mathrm{~d}$. The plasma renin activity (PRA) and aldosterone level were above the reference ranges throughout the experiment, which suggests that $\mathrm{Na}$ deficiency existed in the subjects. However, the uri- nary $\mathrm{Na}$ excretion was about the same as that which had been ingested in the given diet. On the other hand, the urine $\mathrm{Ca}$ and $\mathrm{Mg}$ were high, while the apparent absorption of $\mathrm{Ca}$ and $\mathrm{Mg}$ were moderate $(21 \pm 5 \%$, $34 \pm 4 \%$, respectively), which resulted in a negative balance of these two elements. It is thus believed that the stored $\mathrm{Na}$ in the bone is eluted to compensate for the low dietary $\mathrm{Na}$ intake, while excess $\mathrm{Ca}$ and $\mathrm{Mg}$ also inevitably flow into the blood stream during bone resorption, which both inhibits intestinal absorption and accelerates urine excretion of these minerals.

\section{Acknowledgments}

The authors would like to thank Drs. V \& V Iyengar (Biomineral Sciences, Bethesda, MD) for their critical revision of the manuscript.

\section{REFERENCES}

1) Nishimuta M, Kodama N, Ono K, Kobayashi S, Suzuki K. 1985. Mineral contents in arm sweat at a low mineral diet with special reference to the onset of physical exercise. J Jap Soc Mg Res (JJSMgR) 4: 13-21 (in Japanese).

2) Nishimuta M, Kodama N, Takeyama H, Toyooka F. 1997. Magnesium metabolism and physical exercise in human. In: Magnesium: Current Status and New Development (Theophanides T, Anastassopoulou J, eds), p 109-113. Kluwer Academic Publishers, Dordrecht.

3) Nishimuta M. 1990. The concept (intra and extra cellular minerals). In: Metal Ions in Biology and Medicine (Collery P, Poirier LA, Manfait M, Etienne J-C, eds), p 69-74. John Libbey Eurotext, Paris.

4) Ishizaki A. 1974. Mineral metabolism. In: Handbook in Nutrition, p 605-608. Gihoudou, Tokyo (in Japanese).

5) Kumegawa M. 1993. Formation and function of osteoclast. Molec Med 30: 1240-1247 (in Japanese).

6) Ministry of Health and Welfare. 1989. Dietary Allowances for the Japanese, Fourth revised ed. Daiichi Shuppan, Tokyo (in Japanese).

7) Resources Council, Science and Technology Agency, Japan. 1982. Standard Tables of Food Composition in Japan, Fourth revised ed. Ookurashou Insatukyoku, Tokyo (in Japanese).

8) Kodama N. 1991. An estimation for reliability of dietary intake of minerals on the calculating method or on duplicating analysis - Comparison among dietary mineral contents calculated by the table in menu and measured in diets made of food exactly followed by the menu used for human mineral balance studies. Ann Rep Natl Inst Health Nutr 40: 59-68 (in Japanese).

9) Nishimuta M, Kodama N, Ono K, Matsumoto Y, Tera T, Yamada H, Kobayashi S. 1988 . Stress induced magnesiuresis in human. J Jap Soc Mg Res (JJSMgR) 7: 123132 (in Japanese).

10) Kanai M (ed). 1993. Handbook for Clinical Examinations, 30th revised ed, p 602-603. Kimbara Shuppan Co, Tokyo (in Japanese).

11) Kodama N, Nishimuta M, Hitachi Y. 1990. Dietary magnesium intake estimation by Standard Tables of Food Composition in Japan. Fourth Revised Edition. J Jap Soc Mg Res (JJSMgR) 9: 1-5 (in Japanese).

12) Akatsu T. 1995. Calcium (Ca). Nippon rinsho 53: 769 771 (in Japanese).

13) Takeyama H, Kodama N, Fuchi T, Nishimuta M. 1997. Magnesium, calcium and phosphorus balances in 
young males at low dietary magnesium levels with or without magnesium supplementation. In: Advanced in Magnesium Research: 1 (Smetana R, ed), p 355-363, John Libbey \& Co, London.

14) Arakawa Y, Suzuki K, Moriyama M. 1995. Magnesium (Mg). Nippon rinsho 53: 762-768 (in Japanese).

15) National Research Council. 1989. Recommended Dietary Allowances, 10th ed. p 250-255. National Academy of Science, Washington.

16) Ministry of Health and Welfare. 1994. Dietary Allowances for the Japanese, Fifth revised ed. Daiichi Shuppan, Tokyo (in Japanese).

17) Suzuki K, Nishimuta M. 1984. Magnesium requirement in Japanese young women. J Jap Soc $M g$ Res (JJSMgR) 3:7-12 (in Japanese).

18) Kenkou·Eiyo Jouhoukennkyuukai. 1999. Recommended Dietary Allowances, 6th revised ed. Daiichishuppan, Tokyo (in Japanese).

19) Itoh R, Suyama Y. 1996. Sodium excretion in relation to calcium and hydroxyproline excretion in a healthy Japanese population. Am J Clin Nutr 63: 735-740.

20) Nishimuta M, Kodama N, Ono K. 1989. Magnesium uresis by risk factors for chronic degenerative diseases.
In: Magnesium in Health and Disease (Itokawa Y, Durlach J, eds), p 279-284. John Libbey \& Co, London.

21) Nishimuta M, Tsuji E, Kodama N, Ono K, Kobayashi S. 1986. Magnesiuresis after butter and egg rich diet in young Japanese females. J Jap Soc Mg Res (JJSMgR) 5: 53-60.

22) Okazaki M, Takahashi J, Kimura H. 1986. Unstable behavior of magnesium-containing hydroxyapatites. Caries Res 20: 324-331.

23) Kim Y, Linkswiler. 1979. Effect of level of protein intake on calcium metabolism and on parathyroid and renal function in the adult human male. J Nutr 109: 13991404.

24) Lutwak L, Whedon D, Lachance PA, Reid JM, Lipscomb HS. 1969. Mineral electrolyte and nitrogen balance studies of the Gemini-VII fourteen-day orbital space flight. J Clin Endocr 29: 1140-1156.

25) Donaldson CL, Hulley SB, Vogel JM, Hattner RS, Bayers JH, Macmillan DE. 1970. Effect of prolonged bed rest on bone mineral. Metabolism 19: 1071-1084.

26) Rambaut PC, Johnston RS. 1979. Prolonged weightlessness and calcium loss in man. Acta Astronautica $\mathbf{6}$ : 1113-1122. 